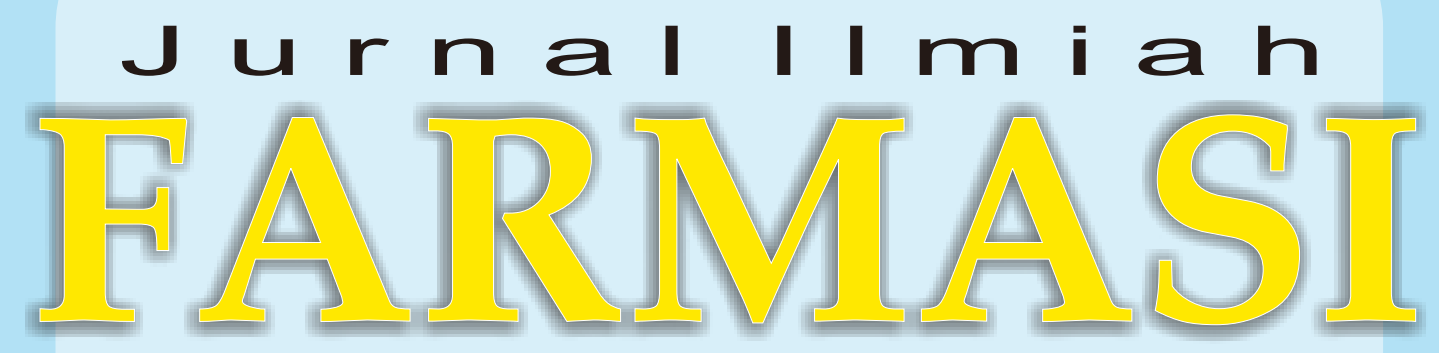

(Scientific Journal of Pharmacy) 
JURNAL ILMIAH FARMASI

(SCIENTIFIC JOURNAL OF PHARMACY)

PIMPINAN UMUM/ PENANGGUNG JAWAB

Dekan Fakultas Matematika dan Ilmu Pengetahuan Alam

Universitas Islam Indonesia

WAKIL PIMPINAN UMUM/ WAKIL PENANGGUNG JAWAB

Ketua Jurusan Farmasi FMIPA UII

\section{MITRA BESTARI}

1. Prof. Dr. Wiryatun Lestariana, Apt

2. Prof. Dr. Zullies Ikawati, Apt

3. Prof. Dr. Sudibyo Martono, Apt

4. Dr. Tedjo Yuwono, Apt

5. Prof. Dr. Dachriyanus, Apt

6. Prof. dr. Iwan Dwiprahasto, MMedSc, PhD

7. Prof. Dr. Lukman Hakim M.Sc., Apt

8. Prof. Dr. Achmad Fudholi, DEA, Apt

9. Prof. Dr. Ibnu Gholib Gandjar, DEA., Apt

\begin{tabular}{ll} 
& \multicolumn{1}{c}{ DEWAN EDITOR } \\
Ketua & : Saepudin, M.Si., Apt \\
Sekretaris & : Rochmy Istikharah, M.Sc., Apt. \\
Anggota & : Vitarani Dwi Ananda Ningrum, M.Si., Apt \\
& Okti R. Mafruhah, MSc., Apt \\
& Dimas Adhi Pradana, MSc., Apt. \\
& Fithria DA. Suryanegara, MSc., Apt. \\
& Ari Wibowo, S.Farm., Apt \\
& Arba Pramudita Ramadani, MSc., Apt. \\
& Oktavia Indrati, S.Farm., Apt.
\end{tabular}

Penerbit

Jurusan Farmasi Fakultas Matematika dan IImu Pengetahuan Alam Universitas Islam Indonesia

Alamat Penerbit Jurusan Farmasi FMIPA UII

Jl. Kaliurang Km. 14,4 Yogyakarta 55584

Telp. (0274) 896439 ext. 3047

Email: jif@uii.ac.id 


\title{
PENGARUH TINGKAT PENDIDIKAN TERHADAP TINGKAT PENGETAHUAN MASYARAKAT TENTANG PENGOBATAN SENDIRI (SELF MEDICATION) DI WILAYAH KABUPATEN SLEMAN JOGJAKARTA
}

\author{
Nanang Munif Yasin
}

Fakultas Farmasi Universitas Gadjah Mada

\begin{abstract}
A B S T R A C T
The motivation for taking self medication increased as well as the growth of drugs production in Indonesia. Self medication will taking a risk, so that it must be followed by the enough society knowledge about medicine. The research about an Influence of Education Level to the Society Knowledge Level about Self Medication in Sleman Yogyakarta had been done. This research tried to shoot the society knowledge level about the aspects corelated with self medication and an influence between the education level increased to the society knowledge level about self medication. From this research, can be hopen that the problems about irrasional drug using in self medication will be decreased. A sample that had been used is the society in Sleman Yogyakarta. The sample had been taken by stratified random sampling. This research was explorative and the data had been gotten by quisioner and interview. The analysis of data had been done by the descriptive statistic analysis and interferention analysis. The result showed that there was a significan difference between education level with medium and high education level aboaut knowledge of self medication. Mean value were $63,35 \pm 7,27 ; 68,56 \pm 6,29 ;$ dan $68,69 \pm 7,72$. The difference specially about drugs classification, side effect of drugs and characteristic of drug. The result showed that if the eduacation level increased, the society knowledge level about self medication will be increased.
\end{abstract}

Key word : drug, self medication, knowledge, education level 